\title{
Substitusi tepung ikan dengan tepung pupa ulat sutera terhadap biaya produksi dan pendapatan pada puyuh (Cortunix cortunix japonica)
}

\section{Silkworm pupae (bombyx mori) meal to subtitute fish meal on production costs and profits on quail laying}

\author{
Reikha Rahmasari ${ }^{1 *}$, Sumiati ${ }^{2}$, Dewi Apri Astuti ${ }^{2}$ dan Rosa Tri \\ Hertamawati ${ }^{1}$ \\ 1Jurusan Peternakan, Politeknik Negeri Jember \\ ${ }^{2}$ IImu Nutrisi dan Teknologi Pakan, Fakultas Peternakan, Institut Pertanian Bogor (IPB \\ University) \\ *Email Korespondensi: reikha.rahma19@polije.ac.id
}

\begin{abstract}
Abstrak. Penelitian ini bertujuan untuk mengetahui pengaruh substituti tepung ikan dengan tepung pupa ulat sutera terhadap biaya produksi dan keuntungan pada puyuh petelur. Penelitian ini menggunakan rancangan acak lengkap (RAL) yang terdiri dari 4 perlakuan, 4 ulangan dengan masing-masing ulangan terdiri dari 10 ekor puyuh. Perlakuan pakan yang diberikan adalah R0: pakan mengandung $8 \%$ tepung ikan, tanpa tepung pupa ulat sutera (kontrol), R1: pakan mengandung tepung pupa ulat sutera menggantikan $25 \%$ protein dari tepung ikan, R2: pakan mengandung tepung pupa ulat sutera menggantikan $50 \%$ protein dari tepung ikan, dan R3: pakan mengandung tepung pupa ulat sutera menggantikan $75 \%$ protein dari tepung ikan. Data yang diperoleh dianalisis menggunakan analisis ragam (ANOVA). Hasil penelitian menunjukkan bahwa substitusi tepung pupa ulat sutera berpengaruh nyata $(P<0,05)$ meningkatkan biaya pakan, pendapatan dan IOFC selama 8 minggu pemeliharaan. Level terbaik untuk menghasilkan pendapatan dan IOFC yang tertinggi adalah penambahan tepung pupa ulat sutera menggantikan $25 \%$ protein dari tepung ikan.
\end{abstract}

Kata kunci: biaya produksi, IOFC, pupa ulat sutera, tepung ikan

\begin{abstract}
This study aims to determine the effect of substitute fish meal with silkworm pupa meal on production costs and profits on quail laying. This study used a completely randomized design (CRD) consisting of 4 treatments, 4 replications and 10 quails each replication. Feed treatments given were R0: feed containing $8 \%$ fish meal, without silkworm pupa meal (control), R1: feed containing silkworm pupa meal replaced 25\% protein from fish meal, R2: feed containing silkworm pupa meal replaced 50\% protein from fish meal; and R3: feed containing silkworm pupa meal replaces $75 \%$ protein from fish meal. The data obtained were analyzed using analysis of variance (ANOVA). The results showed that silkworm pupa meal substitution significantly affected $(P<0.05)$ increase the feed cost, income, and IOFC for 8 weeks of maintenance. The best level for generating income and the highest IOFC is addition of silkworm pupae meal to replace $25 \%$ of protein from fish meal. Level terbaik? Ada di Abstrak bahasa Indonesia
\end{abstract}

Keywords: cost of feed, IOFC, silkworm pupae, fish meal 
Rahmasari et al.

ANIMPRO: Conference of Applied Animal Science Proceeding Series

\section{PENDAHULUAN}

Telur puyuh merupakan bahan pangan sumber protein hewani yang cukup banyak dikonsumsi oleh masyarakat Indonesia. Rata-rata konsumsi telur puyuh per kapita pertahun dari tahun 2015 sebesar 6,67 butir meningkat ditahun 2016 menjadi 7,77 butir (Ditjen PKH, 2017). Ketersediaan pakan baik dari segi kualitas, kuantitas dan kontinuitas menjadi salah satu faktor penting keberlanjutan usaha peternakan. Pakan menjadi faktor yang sangat penting karena memberikan kontribusi $70-80 \%$ dari total biaya produksi (Pratama, Harahap, \& Ali, 2020). Sebagian besar bahan pakan yang digunakan oleh industri maupun peternak berasal dari bahan pakan import, salah satunya adalah tepung ikan. Harga tepung ikan impor lebih mahal, tetapi kualitasnya lebih baik dibandingkan dengan tepung ikan lokal (protein kasar <55\%, mutu III) (SNI, 2006). Oleh karena itu, diperlukan alternatif bahan pakan pengganti/substitusi agar dapat mengurangi penggunaan tepung ikan atau bahan pakan sumber protein lainnya yang masih import. Bahan pakan alternatif yang mempunyai peluang/potensial adalah penggunaan insect, seperti pupa ulat sutera.

Pupa ulat sutera merupakan limbah industri dari pemintalan benang sutera. Pupa ulat sutera potensial dijadikan bahan pakan karena usaha benang sutera sangat potensial. Menurut Estetika \& Endrawati (2018), usaha peternakan ulat sutera mempunyai potensi yang tinggi karena harga kain sutera yang tinggi. Pusat-pusat produksi ulat sutera di Indonesia berada di Sulawesi Selatan, yang terletak di kabupaten Soppeng, Wajo dan Sidrap. Di Bulukumba dan beberapa kabupaten lain memiliki potensi lahan seluas 2524,8 hektar yang dapat digunakan untuk budidaya ulat sutera (Balai Persuteraan Alam, 2010). Pupa ulat sutera merupakan bagian dari limbah pemintalan benang sutera yang mencapai $86,84 \%$ dari total kokon. Jumlah yang banyak tersebut menjadi peluang pupa ulat sutera untuk dijadikan bahan pakan. Selain potensial secara jumlah, pupa ulat sutera juga potensial karena kandungan nutriennya. Mangisah, Supadmo, \& Zuprizal (2004), kandungan protein kasar tepung pupa ulat sutera mencapai 58,28\% dan lemak kasar $28,93 \%$. potensi jumlah dan kandungan nutrien tersebut, pupa ulat sutera dapat dijadikan kandidat bahan pakan pengganti/substitusi bahan pakan sumber protein. Penelitian ini bertujuan untuk mengetahui pengaruhi substitusi tepung pupa ulat sutera terhadap produktivitas puyuh petelur sehingga berdampak pada biaya produksi (pakan), pendapatan dan income over feed cost (IOFC).

\section{MATERI DAN METODE}

Penelitian ini dilaksanakan di kandang C, Fakultas Peternakan, Institut Pertanian Bogor. Pupa ulat sutera diperoleh dari "Pabrik Benang Sutera" PSA Ragaloh, KBM Agroforestri, Perum Perhutani Unit 1, Telogowungu, Jawa Tengah. Tepung pupa ulat sutera dan ransum dianalisis proksimat di Laboratorium IImu dan Teknologi Pakan, Fakultas Peternakan, Institut Pertanian Bogor.

\section{Materi Penelitian}

Materi yang digunakan dalam penelitian adalah 160 ekor puyuh umur 5 minggu, tepung pupa ulat sutera, bahan pakan jagung, dedak padi, bungkil kedelai, tepung ikan, minyak, $\mathrm{CaCO}_{3}, \mathrm{DCP}, \mathrm{DL}-$ Methionine, garam dan premix. Ransum disusun isokalori dan isoprotein sesuai kebutuhan, yaitu energi metabolis $2950 \mathrm{kkal} / \mathrm{kg}$ dan protein kasar 18\% (Leeson \& Summers, 2008). Kandang yang digunakan adalah kandang kelompok ukuran $60 \times 60 \times 45 \mathrm{~cm}$ sebanyak 16 buah.

\section{Metode Penelitian}

\section{Pembuatan tepung pupa ulat sutera}

Kokon kering siap panen direbus sebelum dipintal. Kokon yang telah dipintal menyisakan limbah berupa pupa ulat sutera yang masih terbungkus oleh sisa benang (selaput). Pupa kemudian dikeluarkan dan dijemur di bawah sinar matahari selama dua sampai tiga hari hingga kering. Pupa kering kemudian diblender untuk memperoleh tepung pupa ulat sutera. Tepung pupa kembali dijemur di bawah sinar matahari selama satu hari agar tepung lebih kering sehingga 
Rahmasari et al.

ANIMPRO: Conference of Applied Animal Science Proceeding Series

lebih tahan lama umur simpannya. Tepung pupa ulat sutera kemudian dianalisis kandungan nutriennya.

\section{Pemeliharaan}

Puyuh yang digunakan adalah puyuh umur lima minggu. Pemeliharaan dilakukan selama 10 minggu yang terdiri dari satu minggu masa adaptasi lingkungan, satu minggu adaptasi ransum perlakuan dan delapan minggu perlakuan. Ransum dan air minum diberikan secara ad libitum. Kandang dan tempat minum dibersihkan setiap pagi hari. Produksi telur dicatat setiap hari dan konsumsi ransum dicatat seminggu sekali.

\section{Perlakuan}

Perlakuan yang diberikan adalah:

$\mathrm{R} 0=$ Ransum tanpa tepung pupa ulat sutera dan mengandung $8 \%$ tepung ikan

$\mathrm{R} 1$ = Ransum dengan tepung pupa menggantikan $25 \%$ protein tepung ikan

$\mathrm{R} 2=$ Ransum dengan tepung pupa menggantikan $50 \%$ protein tepung ikan

$\mathrm{R} 3=$ Ransum dengan tepung pupa menggantikan $75 \%$ protein tepung ikan

Tabel 1. Komposisi dan kandungan nutrien ransum perlakuan

\begin{tabular}{|c|c|c|c|c|}
\hline \multirow{2}{*}{ Bahan Baku } & \multicolumn{4}{|c|}{ Perlakuan } \\
\hline & R0 & $\mathrm{R} 1$ & $\mathrm{R} 2$ & R3 \\
\hline & & & ) $\ldots \ldots \ldots \ldots$ & \\
\hline Jagung & 50,13 & 50,09 & 50,35 & 51,3 \\
\hline Dedak padi & 6,87 & 6,3 & 6,09 & 6 \\
\hline Bungkil kedelai & 23 & 23,43 & 22,9 & 22,3 \\
\hline Tepung ikan & 8 & 6 & 4 & 2 \\
\hline Tepung pupa & 0 & 2,08 & 4,16 & 6,25 \\
\hline Minyak sawit & 4,5 & 4,45 & 4,5 & 4,2 \\
\hline $\mathrm{CaCO}_{3}$ & 6,6 & 6,75 & 6,9 & 6,85 \\
\hline DCP & 0 & 0 & 0,3 & 0,3 \\
\hline DL-Methionine & 0,2 & 0,2 & 0,1 & 0,1 \\
\hline Garam & 0,2 & 0,2 & 0,2 & 0,2 \\
\hline Premix & 0,5 & 0,5 & 0,5 & 0,5 \\
\hline Total & 100 & 100 & 100 & 100 \\
\hline \multicolumn{5}{|l|}{ Kandungan nutrien } \\
\hline Energi bruto $(\mathrm{kkal} / \mathrm{kg})^{1}$ & 3262 & 3216 & 3309 & 3316 \\
\hline Protein kasar (\%) ${ }^{2}$ & 17,27 & 17,08 & 16,77 & 17,34 \\
\hline Serat kasar $(\%)^{2}$ & 2,11 & 2,62 & 2,60 & 2,51 \\
\hline Lemak kasar $(\%)^{2}$ & 3,84 & 4,64 & 5,67 & 5,09 \\
\hline $\mathrm{Ca}(\%)^{3}$ & 3,08 & 3,03 & 3,04 & 2,91 \\
\hline $\mathrm{P}$ tersedia $(\%)^{3}$ & 0.52 & 0.45 & 0,45 & 0.39 \\
\hline
\end{tabular}

Keterangan: ${ }^{1}$ Hasil analisis di Balai Penelitian Ternak Ciawi, Bogor, $2014{ }^{2}$ Hasil analisis di Laboratorium IImu dan Teknologi Pakan Fakultas Peternakan IPB, $2014{ }^{3}$ Hasil perhitungan. R0= Ransum tanpa tepung pupa ulat sutera dan mengandung $8 \%$ tepung ikan; R1= Ransum dengan tepung pupa menggantikan $25 \%$ protein tepung ikan; R2 = Ransum dengan tepung pupa menggantikan $50 \%$ protein tepung ikan; R3 = Ransum dengan tepung pupa menggantikan $75 \%$ protein tepung ikan .

\section{Parameter}

Biaya produksi. Biaya produksi adalah biaya yang diperoleh dari total konsumsi ransum $(\mathrm{kg})$ dikalikan dengan harga ransum.

Biaya produksi $=$ Konsumsi ransum $(\mathrm{kg}) \mathrm{x}$ Harga ransum $(\mathrm{Rp})$

Pendapatan. Pendapatan diperoleh dari besarnya uang yang dihasilkan dari produksi telur. Pendapatan dihitung dengan total telur yang dihasilkan (butir) dikalikan dengan harga telur (Rp). 
Rahmasari et al.

ANIMPRO: Conference of Applied Animal Science Proceeding Series

Pendapatan = Jumlah terlu (butir) $\mathrm{x}$ Harga telur (Rp)

Income Over Feed Cost (IOFC). IOFC merupakan parameter untuk mengukur besarnya keuntungan usaha yang diperoleh dengan menghitung selisih biaya produksi pakan dengan pendapatan yang diperoleh.

IOFC = Pendapatan (Rp) - Biaya produksi $(\mathrm{Rp})$

\section{Analisis data}

Rancangan percobaan yang digunakan pada penelitian ini adalah rancangan acak lengkap (RAL), terdiri dari 4 perlakuan dengan 4 ulangan, masing-masing ulangan terdiri dari 10 ekor puyuh. Model matematikanya adalah sebagai berikut:

Keterangan:

$$
Y_{i j}=\mu+\alpha_{i}+\varepsilon_{i j}
$$

$Y_{i j} \quad:$ Nilai pengamatan pada perlakuan ke-i dan ulangan ke-j

$\mu \quad$ : Nilai rataan umum

$\alpha_{i} \quad:$ Efek perlakuan taraf ke-i

$\varepsilon_{\mathrm{ij}} \quad$ : galat perlakuan ke-i dan ulangan ke-j yang menyebar normal

Data yang diperoleh dianalisis menggunakan analisis ragam (ANOVA), jika terdapat perbedaan nyata diantara perlakuan maka dilanjutkan dengan uji jarak Duncan (Mattjik dan Sumertajaya, 2002). Pengolahan data menggunakan software statistik SPSS 16.0.

\section{HASIL DAN PEMBAHASAN}

Data hasil penelitian, mengenai pengaruh substitusi tepung pupa ulat sutera terhadap tepung ikan pada biaya produksi, pendapatan dan IOFC disajikan pada Tabel 2.

Tabel 2. Rataan konsumsi pakan, produksi telur, biaya produksi, pendapatan dan IOFC selama 8 minggu perlakuan

\begin{tabular}{lcccc}
\hline \multicolumn{1}{c}{ Parameter } & $\mathrm{R} 0$ & $\mathrm{R} 1$ & $\mathrm{R} 2$ & $\mathrm{R} 3$ \\
\hline Konsumsi pakan (g/ekor) & $841,77^{\mathrm{a}}$ & $929,51^{\mathrm{b}}$ & $951,61^{\mathrm{b}}$ & $920,40^{\mathrm{b}}$ \\
Produksi telur (butir/ekor) & $25,23^{\mathrm{a}}$ & $32,73^{\mathrm{c}}$ & $27,76^{\mathrm{ab}}$ & $29,8^{\mathrm{bc}}$ \\
Biaya produksi (Rp/ekor) & $5888,50^{\mathrm{a}}$ & $6520,23^{\mathrm{b}}$ & $6325,82^{\mathrm{ab}}$ & $6299,96^{\mathrm{ab}}$ \\
Pendapatan (Rp/ekor) & $8831,25^{\mathrm{a}}$ & $11453,75^{\mathrm{c}}$ & $9716,88^{\mathrm{ab}}$ & $10430^{\mathrm{bc}}$ \\
IOFC (Rp/ekor) & $2942,76^{\mathrm{a}}$ & $4933,52^{\mathrm{b}}$ & $3391,05^{\mathrm{a}}$ & $4130,04^{\mathrm{ab}}$ \\
\hline
\end{tabular}

Superskrip yang berbeda pada baris yang sama menunjukkan perbedaan yang nyata $(P<0,05)$

\section{Biaya Produksi}

Biaya produksi selama penelitian diperoleh berdasarkan besarnya konsumsi pakan (g/ekor) dikalikan dengan harga pakan $(\mathrm{Rp} / \mathrm{kg})$. Harga pakan dari masing-masing perlakuan per kilogramnya adalah R0: Rp 6.242,- ; R1: Rp 6.966,-; R2: Rp 7.590,- dan R3: Rp 8.350,-. Hasil analisis menunjukkan bahwa pemberian tepung pupa ulat sutera nyata meningkatkan biaya produksi pada puyuh petelur $(\mathrm{P}<0,05)$. Biaya produksi tertinggi pada perlakuan $\mathrm{R} 1$ (ransum dengan pupa ulat sutera menggantikan $25 \%$ protein dari tepung ikan). Biaya produksi pada perlakuan tersebut mencapai Rp 6.520,23/ekor. Besarnya biaya produksi sebanding dengan biaya pakan dan konsumsi pakan oleh puyuh selama pemeliharaan. Harga pakan dari setiap perlakuan berbeda-beda tergantung dari jumlah setiap bahan pakan yang digunakan. Jumlah bahan pakan yang signifikan berbeda adalah penggunaan tepung ikan dan tepung pupa ulat sutera. Pupa ulat sutera merupakan hasil sampingan (limbah) pemintalan benang sutera, 
Rahmasari et al.

ANIMPRO: Conference of Applied Animal Science Proceeding Series

sehingga nilai ekonominya tidak ada. Meskipun demikian, untuk menghasilkan tepung pupa ulat sutera membutuhkan biaya sekitar Rp 10.000 - 20.000/kg tepung pupa kering.

Konsumsi pakan selama 8 minggu pemeliharaan terlihat berbeda nyata antara perlakuan kontrol dengan perlakuan substitusi tepung pupa ulat sutera. Konsumsi pakan (g/ekor) selama 8 minggu pemeliharaan menunjukkan bahwa perlakuan substitusi tepung pupa ulat sutera nyata lebih tinggi $(P<0,05)$ dibandingkan dengan kontrol (tanpa tepung pupa ulat sutera). Hal tersebut menunjukkan bahwa penambahan tepung pupa ulat sutera tidak memberikan dampak negatif pada total konsumsi ransum. Rahmasari et al. (2014) secara fisik (tekstur dan warna) dari tepung pupa ulat sutera hampir sama dengan tepung ikan. Selain itu, aromannya juga mempunyai kesamaan dengan tepung ikan. Kedua faktor tersebut dapat menjadi alasan mengapa substitusi tepung ikan dengan tepung pupa ulat sutera tidak memberikan dampak negatif pada konsumsi ransum.

\section{Pendapatan}

Pendapatan diperoleh dari hasil penjualan telur puyuh yang dihasilkan selama pemeliharaan. Pendapatan di sini tidak mempertimbangkan adanya total biaya (investasi dan operasional). Menurut Sanjaya, Amalia, \& Yasid (2016) untuk mendapatkan nilai pendapatan bersih dari suatu usaha dihitung dengan mengurangi nilai total revenue dengan total biaya (investasi dan operasional). Produksi telur puyuh rata-rata per ekor selama 8 minggu pemeliharaan ditampilkan pada Tabel 2. Harga jual telur puyuh disesuaikan dengan harga yang ada di masyarakat, yaitu Rp 500,-/butir. Pendapatan yang dihasilkan pada pakan dengan substitusi tepung pupa ulat sutera menunjukkan hasil yang berbeda nyata $(p<0,05)$ dalam meningkatkan nilai pendapatan. Perlakuan dengan substitusi pupa ulat sutera sebanyak 25\% (P1) menunjukkan nilai pendapatan yang paling tinggi dan perlakuan tanpa tepung pupa ulat sutera (P0) mempunyai nilai pendapatan paling rendah. Nilai tersebut sejalan dengan produksi telur yang dihasilkan pada perlakuan substitusi tepung pupa ulat sutera lebih tinggi dibandingkan dengan perlakukan kontrol, sehingga jumlah telur yang dijual lebih banyak.

\section{IOFC}

IOFC (Income Over Feed Cost) adalah pendapatan kotor yang dihitung dengan pendapatan dikurangi dengan biaya pakan selama pemeliharaan (Rp/ekor) (Nuningtyas, 2014). Berdasarkan Tabel 2, nilai IOFC menunjukkan hasil berbeda nyata $(p<0,05)$ pada setiap perlakuan. Pelakuan dengan substitusi tepung pupa ulat sutera $25 \%$ (P1) mempunyai nilai IOFC paling tinggi (Rp 4933,52/ekor) dan nilai terendah adalah P0 (tanpa substitusi) yaitu Rp 2942,76/ekor. Nilai tersebut sejalan dengan nilai pendapatan dan biaya pakan dari masing-masing perlakuan yang menunjukkan hasil berbeda nyata $(p<0,05)$. Perlakuan subsitusi dengan tepung pupa ulat sutera mempunyai nilai IOFC yang lebih besar dibandingkan dengan kontrol meskipun jumlah konsumsi pakan lebih besar dan biaya produksi (pakan) lebih besar, tetapi produksi telur yang dihasilkan oleh perlakuan substitusi lebih besar dari pada perlakuan kontrol. Faktor-faktor yang mempengaruhi besarnya nilai IOFC adalah bobot tubuh akhir, konsumsi ransum, harga ransum dan harga jual ternak (Tantalo, 2009).

\section{KESIMPULAN}

Substitusi protein tepung ikan dengan tepung pupa ulat sutera dapat meningkatkan biaya produksi pakan. Meskipun demikian, substitusi tepung pupa ulat sutera dapat meningkatkan besarnya pendapatan dan nilai IOFC. Subsitusi $25 \%$ tepung pupa ulat sutera memberikan hasil terbaik dalam meningkatkan pendapatan dan nilai IOFC selama pemeliharaan.

\section{DAFTAR PUSTAKA}

Balai Persuteraan Alam. (2010). Statistik Pengembangan Persuteraan Alam Tahun 2010. Departemen Kehutanan. Direktorat Jenderal Rehabilitasi Lahan dan Perhutanan Sosial. Bili-Bili, Februari 2010. 
Rahmasari et al.

ANIMPRO: Conference of Applied Animal Science Proceeding Series

Ditjen PKH. (2017). Periode Tahun 2016. Data Makro Sekertariat PKH Bagian Evaluasi Dan Layanan Rekomendasi, pp. 2015-2016.

Estetika, Y., \& Endrawati, Y. C. (2018). Produktivitas Ulat Sutera ( Bombyx mori L .) Ras BS09 di Daerah Tropis. Jurnal IImu Produksi Dan Teknologi Hasil Peternakan, 06(3), 104112.

Leeson, S., \& Summers, J. D. (2008). Commercial Poultry Nutrition (3th ed.). Guelph, Ontario, Canada: Nottingham University Press.

Mangisah, I., Supadmo, \& Zuprizal. (2004). Evaluasi nilai nutritif tepung pupa ulat sutera. Buletin Peternakan, 26(1), 20-26.

Nuningtyas, Y. F. (2014). Pengaruh penambahan tepung bawang putih (Allium sativum) sebagai aditif terhadap penampilan produksi ayam pedaging. J. Ternak Tropika, 15(1), $65-73$.

Pratama, Y., Harahap, A. E., \& Ali, A. (2020). Peforma Burung Puyuh (Coturnix coturnix japonica) Periode Grower yang Diberi Pakan Berbahan Tepung Daun Ubi Kayu. Jurnal Peternakan Sriwijaya, 9(1), 16-25. https://doi.org/10.33230/jps.9.1.2020.11510

Rahmasari, R., Sumiati, S., \& Astuti, D. A. (2014). The effect of silkworm pupae (bombyx mori) meal to substitute fish meal on production and physical quality of quail eggs (cortunix cortunix japonica). Journal of the Indonesian Tropical Animal Agriculture, 39(3), 180-187. https://doi.org/10.14710/jitaa.39.3.180-187

Sanjaya, B., Amalia, \& Yasid, H. (2016). Analisis kelayakan usaha burung puyuh petelur (Cortunix cortunix japonica) di Kelurahan Tebing Tinggi Okura Kecamatan Rumbai Pesisir Kota Pekanbaru. Jurnal Ilmiah Pertanian, 13(1), 47-58.

Tantalo, S. (2009). Perbandingan performans dua strain broiler yang mengonsumsi air kunyit. Jurnal IImiah IImu-IImu Peternakan, 12(3), 146-152. 